\title{
Effect of haemolysate preparation on measurement of red cell folate by a radioisotopic method
}

\author{
C R Gilois, J Stone, A P Lai, A S Wierzbicki
}

\begin{abstract}
The effects of varying the method of preparation of haemolysates on the measurement of red cell folate concentration were investigated using the Simultrac kit. The concentration of ascorbic acid did not have any significant effect on the assayed concentrations of folate, but lower concentrations were obtained when the incubation time was increased. Folate was stable for 14 days in cells when they were stored at $4^{\circ} \mathrm{C}$ and for seven days at $-25^{\circ} \mathrm{C}$, but instability was increased by storage in ascorbic acid, by the use of stored $\left(4^{\circ} \mathrm{C}\right)$ ascorbic acid, and by preparing the haemolysates by freezethaw cycling. It is recommended that haemolysates should be diluted in fresh ascorbic acid, at a concentration of $10 \mathrm{~g} / \mathrm{l}$, incubated for 60 minutes in the dark and stored at $-20^{\circ} / 25^{\circ} \mathrm{C}$ before being assayed.
\end{abstract}

The quantitation of erythrocyte tetrahydrofolic acid (folate) derivatives depends on several factors, including the methodology of the radioisotopic assay. The most important are heating and acidification of folate during the extraction process and the $\mathrm{pH}$ of the binding reactions during the adsorption of folate on to the carrier proteins. ${ }^{1-6}$ Other factors include the preparation and storage of the samples before the assay. The degree of haemolysis and the period of frozen storage influence the amount of folate measured by radioisotopic assays. ${ }^{1-4}$ The oxidation state of the pteridine ring, the carbon derivative on the $\mathrm{N}-5$ position, ${ }^{7}$ and the number of glutamate moieties ${ }^{89}$ have also been suggested as factors which may explain the interassay variability due to their effect on the affinity of folates for milk binding proteins.

The purpose of haemolysate preparation is: (a) to extract folate from the cells; (b) to hydrolyse the polyglutamates ${ }^{10}$ to monoglutamates (the form of folate measured by radioisotopic assays); (c) to provide a suitable $\mathrm{pH}$ for the endogenous enzymes to hydrolyse polyglutamates; (d) to dilute the folate to within the optimal area of the assay curve; (e) to protect the monoglutamates from oxidation. Haemolysates are prepared by diluting whole blood under reducing conditions and incu- bating the preparations to allow the endogenous conjugases to hydrolyse the folate and to convert the polyglutamates to monoglutamates. Haemolysates are stored at -20 $25^{\circ} \mathrm{C}$ until use.

There is no uniformly accepted procedure for the preparation of haemolysates (table 1), and the interlaboratory variability is large. We examined the effects of different haemolysate preparation procedures on the measurement of red cell folate concentrations using a solid phase, boil, dual assay kit.

\section{Methods}

The sample size for the study was calculated ${ }^{11}$ to allow methodological differences to be rendered insignificant $(\mathrm{p}<0.05)$ while allowing a difference of $20 \mu \mathrm{g} / 1$ to be detected between sample means of the groups studied. Twelve samples were necessary for the study.

The Becton Dickinson solid phase, boil, dual assay (Simultrac) folate assay kit was used according to the manufacturer's recommended protocol. Samples were counted on a Crystal II gamma counter and the results were calculated using the data reduction unit with a $\log /$ linear function.

In each study 12 blood specimens preserved with EDTA sent to the laboratory were selected at random and haemolysates prepared. For practical reasons different pools of samples were used for each study.

The effect of ascorbic acid concentration on folate concentrations was studied by using haemolysates prepared on the day of venesection (day 1) and divided into 3 aliquots after dilution at $1 / 21$ in fresh ascorbic acid. Individual aliquots were diluted in $2 \mathrm{~g} / 1,5 \mathrm{~g} / 1$, or $10 \mathrm{~g} / 1$ ascorbic acid. All samples were incubated for 90 minutes in the dark, stored for seven days at $-25^{\circ} \mathrm{C}$, and assayed on day 8 . All haemolysates were prepared for the ensuing studies using a $1 / 21$ dilution in $2 \mathrm{~g} / 1$ ascorbic acid.

The effect of varying the haemolysate incubation time on folate concentrations was examined in three sets of lysates by (a) immediate freezing; (b) incubation at $20^{\circ} \mathrm{C}$ for 90 minutes; (c) incubation for 180 minutes. All samples were stored at $-25^{\circ} \mathrm{C}$. All samples were assayed on day 8 . Ensuing studies used an incubation period of 90 minutes at room tem- 
Table 1 Haemolysate preparation procedures for commercial kits *

\begin{tabular}{|c|c|c|c|}
\hline Manufacturer & Kit & $\begin{array}{l}\text { Ascorbic acid } \\
\text { concentration }\end{array}$ & $\begin{array}{l}\text { Storage procedure for } \\
\text { haemolysates }\end{array}$ \\
\hline Amersham plc & $\begin{array}{l}\text { B12/folate } \\
\text { "dual assay" }\end{array}$ & $\begin{array}{l}10 \mathrm{~g} / 1 \text { (sodium } \\
\text { salt) }\end{array}$ & Freeze immediately \\
\hline Immunodiagnostics Ltd & Combostat II & $2 \mathrm{~g} / 1$ & $\begin{array}{l}\text { Incubate at } 20-25^{\circ} \mathrm{C} \text { for } 90 \\
\text { minutes in dark }\end{array}$ \\
\hline $\begin{array}{l}\text { Becton Dickinson } \\
\text { Immunodiagnostics Ltd }\end{array}$ & Simultrac & $2 \mathrm{~g} / 1$ & $\begin{array}{c}\text { Incubate at } 20-25^{\circ} \mathrm{C} \text { for } 90 \\
\text { minutes in dark }\end{array}$ \\
\hline Biorad Laboratories Ltd & Quataphase & $4 \mathrm{~g} / 1$ & $\begin{array}{l}\text { Freeze whole blood until } \\
\text { assay }\end{array}$ \\
\hline
\end{tabular}

*All samples stored at $-25^{\circ} \mathrm{C}$.

perature, in the dark, and storage at $-25^{\circ} \mathrm{C}$.

Red cell folate stability was assessed by preparing haemolysates on day 1 and then preparing subsequent specimens from the original EDTA specimen (stored at $4^{\circ} \mathrm{C}$ ) after seven and 14 days. All samples were assayed on day 15.

The stability of folate in whole blood stored in EDTA at $-25^{\circ} \mathrm{C}$ for seven days was assessed by preparing a set of haemolysates on day 1 . The original EDTA samples were stored at $-25^{\circ} \mathrm{C}$ and a second set of haemolysates was prepared after seven days. All samples were assayed on day 8 .

The stability of folate stored in ascorbic acid at $-25^{\circ} \mathrm{C}$ was examined by assaying sets of haemolysates after one, seven, and 21 days storage at $-25^{\circ} \mathrm{C}$, respectively. One set of haemolysates was subjected to a freeze-thaw cycle (three hours at room temperature) and compared with a set kept at $-25^{\circ} \mathrm{C}$ after eight days to assess the stability of the folate to temperature cycling.

The effect of ascorbic acid stability on folate concentrations was assessed by using haemolysate prepared under standard conditions using (a) fresh ascorbate, (b) seven day old ascorbic acid-stored at $4^{\circ} \mathrm{C}$; (c) seven day old ascorbic acid stored at $-25^{\circ} \mathrm{C}$. All were assayed after eight days.

A matched pair $t$ test was used to analyse the results when two treatment groups were present, and a two way analysis of variance was used when more than two groups were present.

\section{Results}

The results are summarised in table 2 . There was no significant difference between folate concentrations when the concentration of ascorbic acid was in the range of $2 \mathrm{~g} / 1$ to $10 \mathrm{~g} / 1$. Significant differences were obtained when the time of haemolysate incubation was reduced or increased. Increased incubation time resulted in a decreased amount of folate.

Folate was stable in red cells stored at $4^{\circ} \mathrm{C}$ over a period of 14 days and preserved with EDTA. Similarly, cellular folate stored at $-25^{\circ} \mathrm{C}$ did not show any deterioration over seven days. When folate was stored in ascorbic acid at $-25^{\circ} \mathrm{C}$, however, significant differences were obtained after one, seven, and 21 days of storage. Folate concentrations were lower after seven days of storage than after one day; they were similar to the concentrations at day 1 after 21 days of storage. Freeze-thaw cycling resulted in a significant fall in folate concentrations. There was an overall difference between the ascorbic acid storage methods; increased concentrations of folate were obtained with ascorbic acid stored for seven days at $4^{\circ} \mathrm{C}$, but there was no significant difference between freshly made and frozen $\left(-25^{\circ} \mathrm{C}\right)$ stored ascorbic acid.

\section{Discussion}

Ascorbic acid within the range of $2 \mathrm{~g} / 1$ and $10 \mathrm{~g} / \mathrm{l}$ produced the same degree of hydrolysis over a period of 90 minutes, and no significant differences were obtained between the folate concentrations measured at these different concentrations. Variation in incubation time, however, affected the amount of folate assayed. This suggests that the hydrolysis and the conversion of polyglutamates to monoglutamates was incomplete after 90 minutes. A fall in the measured concentrations occurred because the affinity of the monoglutamates for the binding proteins is lower than that of the polyglutamates. ${ }^{9}$ Similar results have been reported by Bain et al using the same kit. ${ }^{12} \mathrm{~A}$ study of the effect of the incubation time on the functional biological activity as measured by $L$ case $i$ showed that the folate concentration fell as conversion proceeded, plateauing after $40 \mathrm{~min}$ utes (when a $10 \mathrm{~g} / 1$ solution of ascorbic acid was used), and indicating that complete conversion has occurred. ${ }^{13}$ A $2 \mathrm{~g} / 1$ solution has a similar

Table 2 Effect of haemolysate preparation on measurement of red cell folate concentrations

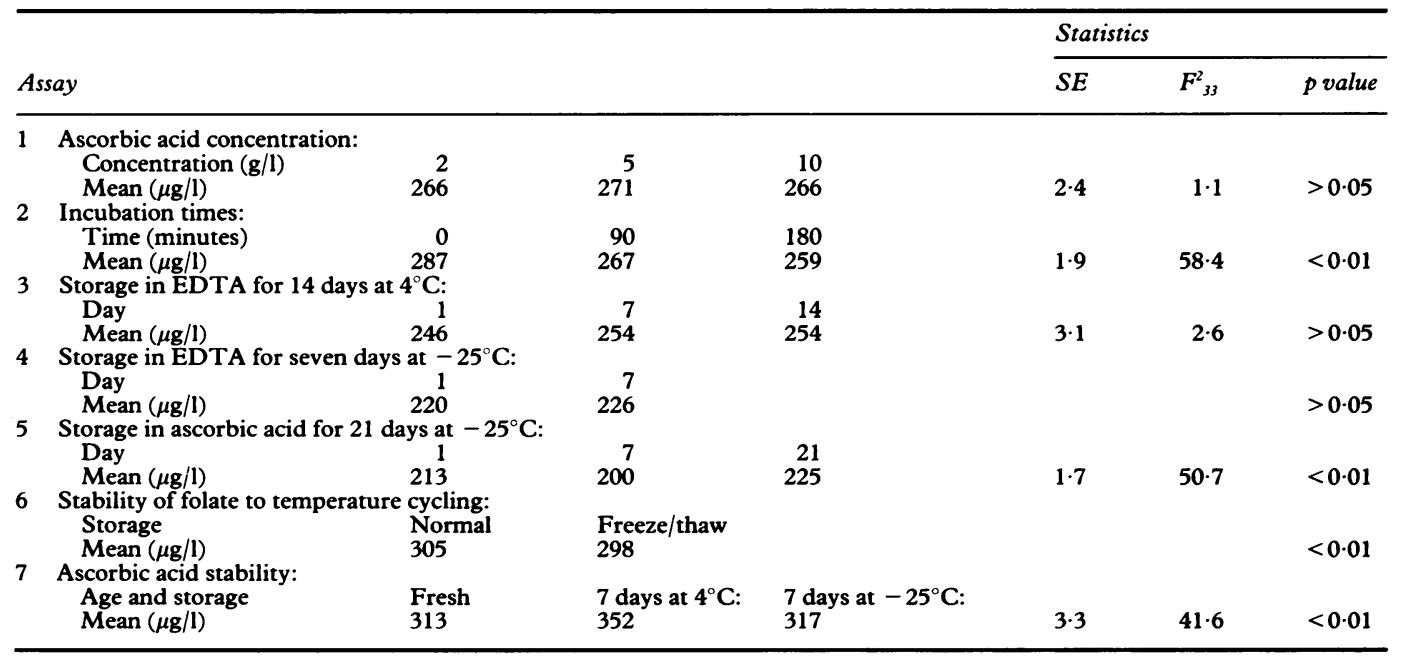


though slower time course. The affinity of binding proteins for polyglutamates increases at high concentrations of folate and decreases at low concentrations, ${ }^{9}$ and the incubation effect seems to be negligible when low folate concentrations were measured. ${ }^{14}$

Cellular folate stored in EDTA at $4^{\circ} \mathrm{C}$ was stable over a period of 14 days, confirming the findings of previous studies. ${ }^{14}$ Similarly, cellular folate stored at $-25^{\circ} \mathrm{C}$ did not show any deterioration over seven days of storage. Significant differences were obtained between one, seven, and 21 days of storage, however, when folate was stored in $2 \mathrm{~g} / 1$ ascorbic acid at $-25^{\circ} \mathrm{C}$. During hydrolysis a mixture of monoglutamates are probably formed with varying amounts of glutamate moieties and some hydrolysis occurs during storage, thus changing the monoglutamate composition and the oxidation state of the haemolysate preparation. Different monoglutamates are known to vary in binding affinity for the milk proteins, ${ }^{9}$ so it is not surprising that differing results are obtained. Storage could also cause the formation of monoglutamate isomers or the formation of formyl monoglutamates, which also vary in avidity for the binding proteins. ${ }^{9}$

Freeze-thaw cycling also affects the folate concentration measured as the additional thawing period changes the monoglutamate to polyglutamate ratio causing a fall in measured folate concentrations.

The age of the ascorbic acid had an important effect on the folate concentrations. Liquid ascorbic acid probably deteriorates and becomes less effective as a reducing agent and so less hydrolysis occurs compared with fresh or frozen ascorbate. More polyglutamates are bound and, therefore, concentrations of folate increase.

The findings of this study provide a basis to explain the interlaboratory variability in the measurement of red cell folate concentrations as shown by the external quality control schemes. Little improvement can be expected unless preparative techniques are standardised.
This and other studies ${ }^{913}$ suggest that users of the Becton Dickinson solid phase folate assay kit should prepare their haemolysates from whole blood stored at $4^{\circ} \mathrm{C}$ for no more than 14 days. The haemolysates should be diluted in freshly made ascorbic acid at a concentration of $10 \mathrm{~g} / 1$ on the day of the assay and incubated for a minimum of 60 minutes in the dark. If a repeat estimation is necessary it should be performed on a freshly prepared sample.

We thank Becton Dickinson for donating the kits for this study We thank Becton Dickinson for donating the kits for this study and Mr D Fish from North Manchester General Hospital for
some useful advice. We also thank Mrs L Dudderidge for typing the manuscript.

1 Rothenberg SP, Da Costa M, Lawson J, et al. The determination of erythrocytes folate concentrations using a two mination of erythrocytes folate concentrations using a two phase $437-45$.

2 Omer A. Factors influencing the release of assayable folate from erythrocytes. J Clin Pathol 1969;22:217-21.

Toennies G, Phillips PM. Blood folic acid studies. J Bio Chem 1959;234:2369-72.

4 Iwai K, Lutner PM, Toennies G. Blood folic acid studie VII. Purification and properties of the folic acid precursors of human erythrocytes. J Biol Chem 1964;239:2365-9.

5 Bird OD, McGlohon VM, Vaitkus JW. Naturally occurring folate in blood and liver of rats. Anal Biochem 1965;12: 18-35.

6 Givas JK, Gutcho S. pH dependence of the binding of folate to milk binders in radioassay of folate. Clin Chem 1975; to milk binc

7 Rothenberg P, Da Costa M. Measurement of red cell folate levels. Br J Haematol 1975;29:189-90.

8 Schreiber C, Waxman S. Measurement of red cell folate levels by $3 \mathrm{H}$ pteroylglutamic acid radioassay. $\mathrm{Br}$ Haematol 1974;27:551-8.

9 Shane B, Tumara T, Stocktad R. Folate assay: A comparison of radioassay and microbiological methods. Clin Chim Acta 1980;100:13-29.

10 Herbert V, Zalusky $R$. Interelations of vitamins $B_{1}$ and folic acid. A clearance study. $J$ Clin Invest 1962;41:1263-8.

11 Armitage P. Statistical methods in medical research. Oxford: Blackwell Scientific Publications, 1983:185-7.

12 Bain BJ, Wickramasinghe SN, Broom GN, et al. Assessment of the value of a competitive protein binding radioassay of folic acid in the detection of folic acid deficiency. $J$ Clin Pathol 1984;37:888-94.

13 Fish DI. Anaemia Symposium. Interregional quality assurance and red cell folate. Abstracts. Becton Dickinson Diagnostic Systems 1988:24-6.

14 Gilois CR, Dunbar DR. Measurement of low serum and red cell folate levels: a comparison of analytical methods. $M e d$ Lab Sci 1987;44:33-44. 